Contents list available at IJRED website

Int. Journal of Renewable Energy Development (IJRED)

Journal homepage: http://ejournal.undip.ac.id/index.php/ijred

\title{
Woodfuel in Rwanda: Impact on Energy, Poverty, Environment and Policy Instruments analysis
}

\author{
Ernest Mazimpaka* \\ Faculty of Applied Sciences, National University of Rwanda, RWANDA
}

\begin{abstract}
Rwanda's geographical and socio-economic situations have shaped the energy situation and limited access to modern fuels. Woodfuel is the main source of energy for households and its trade a source of income and jobs in rural areas. Currently $85.2 \%$ of households' land holding is less than 1 ha, insufficient to grow food and woodfuel for a household of the average size of 5.5 persons. Without well documented reports of the individual impact of each deforestation factor, woodfuels have been most blamed. This paper investigates how the current woodfuel industry impacts on energy, poverty and forests and analyses the woodfuel policy instruments. Considering woodfuel consumption under an only environmental or energy perspective has resulted in a search for a narrowly environmental or energy solution. Both failed to solve the problem of forest depletion. Current regulations limit the benefits traditionally derived from woodfuel commoditisation leading to a negative attitude towards policy instruments. The processes involved in producing charcoal and using it as a cooking fuel is inefficient and resource intensive. The barriers to large dissemination of improved cooking stoves include availability, relatively low cost of woodfuels, lack of improved stove diversity on the local market and weak government policy in regard to the woodfuel industry. Policies aiming to substitute or reduce woodfuel consumption, have not achieved the desired results and their implementations have not unarguably reduced deforestation. The paper recommends the community-based woodfuel production as sustainable management approaches to mobilise community support for sustainable forestry management and woodfuel production.
\end{abstract}

Keywords: bans, energy, forest degradation, policies, poverty, woodfuels

Article History: Received December 12, 2013; Received in revised form Jan 07, 2014; Accepted January 11, 2014; Available online

How to Cite This Article: Mazimpaka, E (2014) Woodfuel in Rwanda: Impact on Energy, Poverty, Environment and Policy Instruments Analysis. Int. Journal of Renewable Energy Development, 3(1),21-32.

http://dx.doi.org/10.14710/ijred.3.1.21-32

\section{Introduction}

The contribution of woodfuel in Rwanda is as high as $86 \%$ to the primary energy balance and about $97 \%$ of households dependent on wood for cooking (NISR 2008a). With the exception of South Africa at 20\% (Statssa 2007) this is the trend throughout sub-Saharan Africa with an average of $80 \%$ relying on woodfuels for cooking. Regionally, in Eastern African Community countries (Burundi, Kenya, Rwanda, Tanzania and Uganda), woodfuel contributes $96.46 \%$ of the total energy consumption (UNDP 2009).

Woodfuel use is often considered as inherently damaging to the environment, but its impacts are not necessarily negative for everyone, as it contributes significantly to alleviating poverty and creating jobs in rural and urban areas.

Some studies in the mid-1970s and early 1980s predicted that population growth and inefficient consumption of woodfuels would decimate forests in Eastern Africa by the end of the 20th century (Kamweti 1984). Others insisted that woodfuel extraction rarely resulted in forest loss (Chidumayo 1993), putting the blame rather on agricultural expansion and extensive grazing. In the 1990s socio-cultural, political and land tenure issues were considered in this area of debate (Mwapamba 2007).

Globally, contributions by direct deforestation factors are as follow: subsistence farming 63\%; permanent agriculture $16 \%$, cattle ranching $6.5 \%$.

\footnotetext{
* Corresponding author:

Email: emazimpaka@yahoo.fr
} 
These three factors contributed $85.5 \%$ while (over) exploitation for woodfuels; (over) exploitation for timber; infrastructure (roads, cities, mines...) contributed to $8 \%, 5.5 \%$ and $1 \%$ respectively (Marcoux 2000). Therefore, particularly in Rwanda and global contribution of woodfuel to deforestation is fairly low.

In Rwanda, no well-documented study has itemized their different contributions, but wood for fuels has tended to be the most blamed, with most guidelines aiming to curb deforestation and environmental abuses focusing on this factor notably a ban on woodfuel production, mainly charcoal with less concern about its role in energy and poverty alleviation.

\section{The Research Question and Method}

To be successful, policy instruments must provide satisfactory outcomes for forests, energy, poverty and environment. That is, the population must benefit from woodfuels as the national dominant energy carrier and source of income and woodfuels must be grown and harvested on an environmentally sound basis. The research objective is to examine the current energy, environment and poverty alleviation impact of woodfuel values chain, its legal and regulatory frameworks and propose strategies which are suitable for both energy production and poverty alleviation in an environment friendly way.

\section{The Energy sector in Rwanda and the role of woodfuel}

Rwanda's energy sector is currently dominated by biomass, diesel and hydro with renewable sources expected to gain more prominence by 2017. Rwanda currently produces 85 MW of electricity with a customer base of 175,000 customers. This represents a $10 \%$ connectivity rate to the grid. Reasons for this include low per-capita incomes but also the low national generation capacity to ensure new connections. In Africa the average electrification level is $40 \%$ and $31 \%$ in SSA (IEA 2010). By 2017, Rwanda intends to have $50 \%$ connectivity and electricity production of $1000 \mathrm{MW}$. This twelve fold increase in electricity production will be attributed to an increase in installed capacity of methane gas, geothermal, energy, regional hydro and peat.

In Rwanda management of the energy sector is split between traditional energy (biomass energy) and modern energy (electricity and petroleum products). In terms of the traditional energy sector the Ministry of Infrastructure deals with user's aspects of biomass such as rational use, efficiency of consumption and the search for alternative fuels to biomass. The supply side is covered under the Ministry of Natural Resources within the forestry and environment departments, which also deals with land ownership. This division may seem logical but there is no coordination between these departments (MININFRA 2007). The electricity sector is controlled by state owned utility 'Energy water and Sanitation Authority- EWSA-". Petroleum products are managed by the Ministry of Commerce.

In terms of primary energy (Primary energy includes fuels used to produce other fuels but does not include the fuels produced. For example primary energy includes wood used for charcoal making but does not include the charcoal produced from that wood), the main source of energy in Rwanda is biomass which accounts, for $86 \%$, petroleum products accounting for $11 \%$ and electricity 3\% (MININFRA 2007) (Fig. 1). On average in SSA woodfuel accounts for $72 \%$, petroleum $23 \%$ and electricity $5 \%$ of the total energy consumption while for the whole continent biomass accounts for more than 30\% (Kebede et al. 2010).

In Rwanda, the sectorial distribution of the net energy consumption is dominated by households, accounting for $91 \%$ of demand, while the transport sector accounts for $4 \%$, industry $3 \%$ and services $2 \%$ (Fig. 2). Compared to the most advanced economy of Africa, in 2006, South Africa's residential consumption accounted for $17.7 \%$, industry for $36.3 \%$ and transport for 25.5\% (ProBEC 2008). For the whole Africa, sectorial distribution shows that residential energy use accounts for $37 \%$ of energy utilised, industry $11 \%$, -

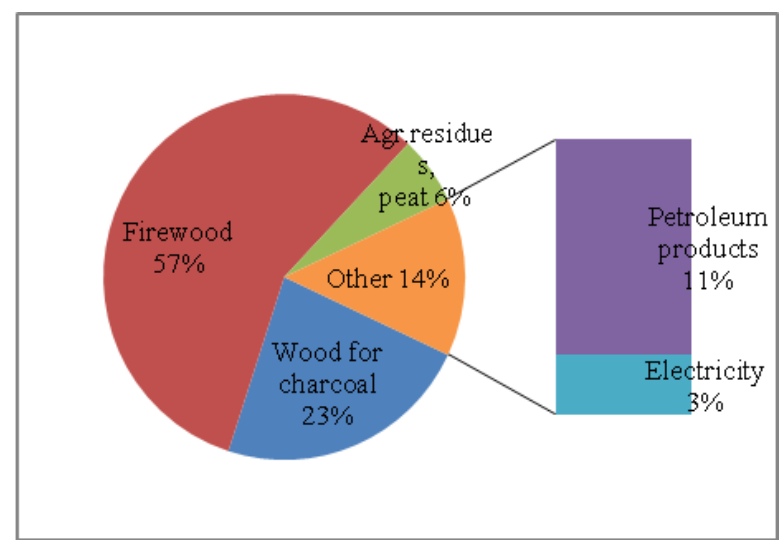

Fig. 1 Primary energy balance in Rwanda (MININFRA 2007)

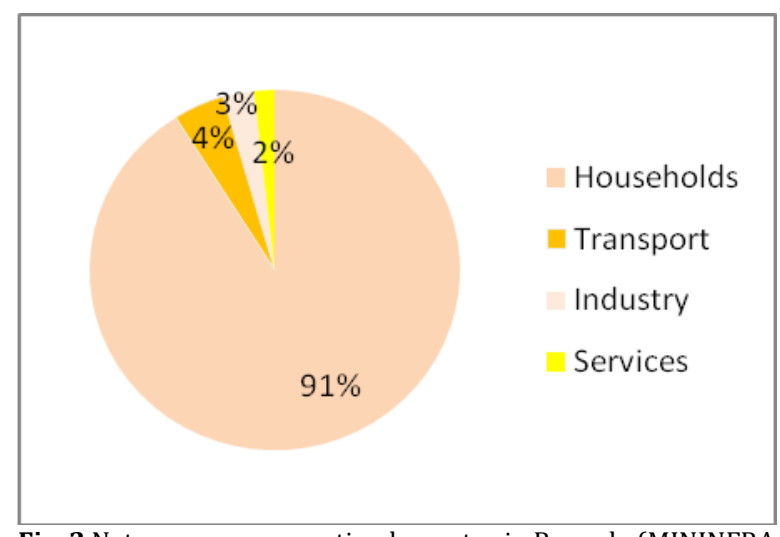

Fig. 2 Net energy consumption by sector in Rwanda (MININFRA 2007) 
-transportation 9\%, agriculture/forestry and commercial/public services each account for $1 \%$, while the remaining $40 \%$ is used by other sectors (Kebede et al. 2010).

\subsection{The modern energy sector}

The 85MW national installed electricity capacity is composed of hydro, thermal (diesel, heavy fuel and methane gas) and solar power. Hydroelectricity accounts for $45.95 \%$ and thermal electricity for $51.09 \%$ of the national generation. This lack of generation diversity could have big challenges in periods of drought or petroleum price crises.

The average yearly demand of 150,000 tons of oil products are all imported. The products are mainly used for transportation and more than $80 \%$ is consumed as diesel or petrol (NISR 2008b). In addition to high inland transport costs from Mombasa $(1792 \mathrm{~km})$ and Dar es Salaam $(1620 \mathrm{~km})$, oil product imports are also subject to different duties and taxes. So on average, retail prices of petroleum products are about $100 \%$ higher than acquisition costs so that imported petroleum products consume more than $40 \%$ of the foreign exchange (REMA 2009).

\subsection{Traditional energy sector}

Most of the energy consumption in Rwanda is in the form of woodfuel which is estimated to be 6 million tons per year (GTZ 2008). MININFRA (2009a) has estimated the rural consumption at 4 million tons. This is likely to remain so in the near or even medium term future, unless income levels substantially increase to enable households to afford modern sources of energy.

Traditional charcoal production was from open access charcoal production from the savannah woodlands in the Eastern natural forests but due to forest depletion it has shifted to private and communal woodlots in the south and southwest of the country (Leach et al. 2009). Combined effect of inflation and increased distance to production site with associated transport costs have increased charcoal prices from US\$ 0.70 a $33 \mathrm{~kg}$ bag in 1994 to approximately US\$ 8.77 a 33 $\mathrm{kg}$ bag in 2009.

In terms of percentage, wood for non energy usage accounts for only $23 \%$, firewood for $28 \%$ and wood for charcoal represents $49 \%$ of the national wood demand (GTZ 2008).

\subsection{Energy Potentials}

Rwanda's dependence on solid fuels does not mean that the country lacks energy resource potentials. All untapped resources for power generation are about 1,400 MW (MININFRA 2007). Development of modern energy resources - additional hydroelectricity, natural gas dissolved in Lake Kivu, peat, and geothermal - have been constrained by small market size, lack of financing and an inadequate institutional framework as some generation power plants need a regional or multilateral agreement and/or high investments (Kivu-border with DRC methane gas and Rusumo-border with Tanzania hydropower projects).

\subsubsection{Hydropower}

Hydropower potential is estimated at $300 \mathrm{MW}$. Regionally, there is considerable untapped hydroelectric potential on the Rusizi (Rusizi III of 145 MW and Rusizi IV of 205 MW) and Akagera (Rusumo falls of 61.5 MW) rivers (Fig. 3), which respectively constitute borders with the DRC and Tanzania, and therefore must be developed on a bilateral or regional basis (MININFRA 2009b).

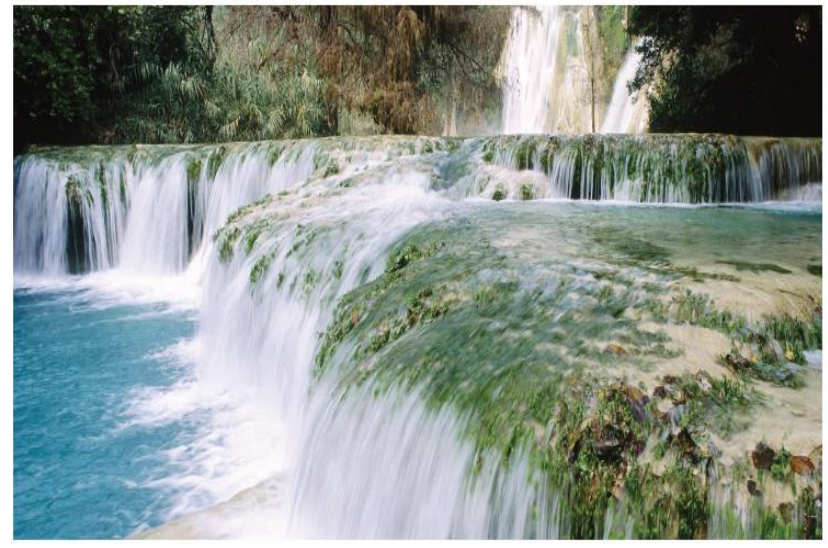

Fig. 3 Rusumo falls

\subsubsection{Methane Gas}

Rwanda also has a unique energy resource in the form of methane gas dissolved in Lake Kivu, which straddles the borders of Rwanda and the DRC. The amount of methane in place is estimated at about 59 billion cubic meters of which 29 billion cubic meters are believed to be economically recoverable (UPEGAZ 2004). The gas has a regeneration capacity of 250 million cubic meters every year (Butare \& Hughes 2004). The methane gas from Lake Kivu has a potential of $750 \mathrm{MW}$.

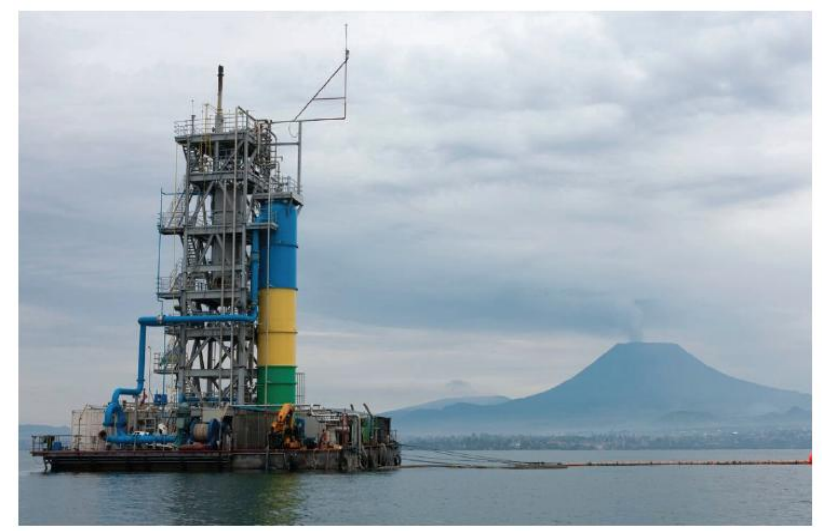

Fig. 4 Pilot exploitation methane to electricity station at Kivu Lake 
A small methane extraction unit installed in 1963 to supply some 8000 cubic meters of methane per day to the local brewery is still operational today. Till recently, no other use was made of Kivu methane gas but in 2008 the first power generation of $1.8 \mathrm{MW}$ was fed into the national power grid.

\subsubsection{Geothermal Energy}

Geothermal energy in Rwanda's volcanic area of the Northern Province and the Western Province is estimated to have a generation capacity of between 170 MW and 320 MW respectively (WB 2008).

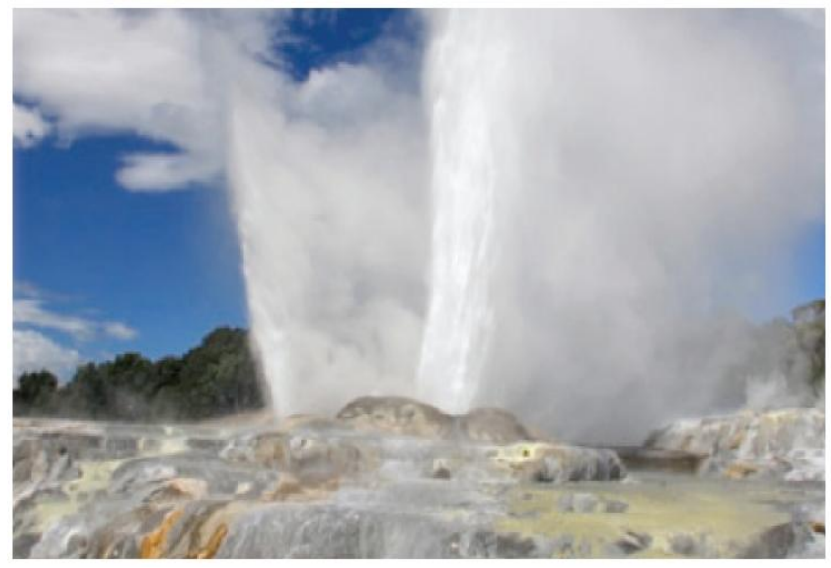

Fig. 5 Geothermal water in the Northern Province of the country

\subsubsection{Solar Energy}

Solar energy, has a potential of $4.5 \mathrm{kWh}$ per $\mathrm{m} 2$ per day. If well promoted this can be a good lighting substitute in remote areas. Solar energy (photovoltaic) is a good option for remote areas for lighting and ICT in schools, offices, clinics and hospitals. Solar water heaters could be used for water heating to reduce the consumption of electricity in hospitality, clinics, hospitals and catering services and households.

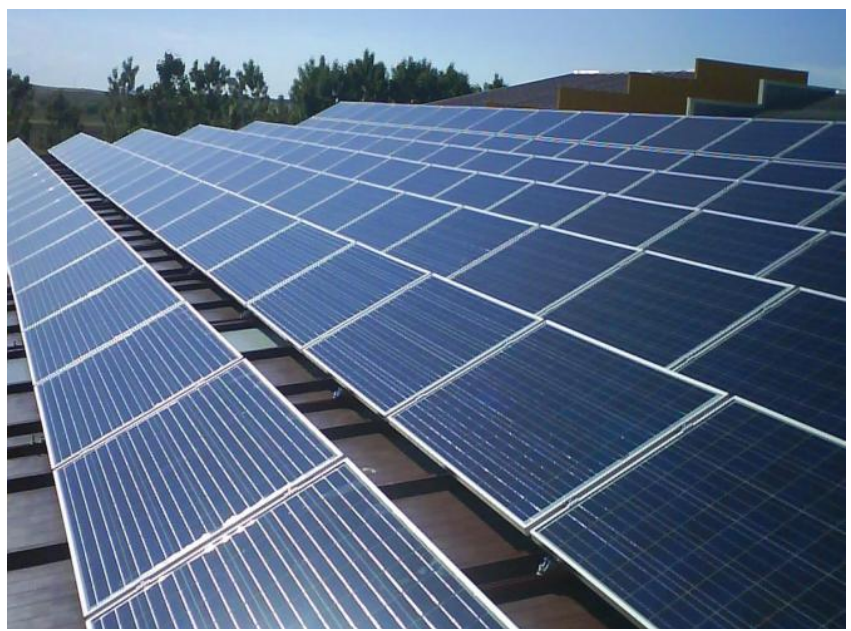

Fig. $6250 \mathrm{kWp}$ solar plant at Jari hill (Kigali city)

\subsubsection{Solar Energy}

Peat as a potential energy source in Rwanda is identified at 155 million dry tons. Since December 2009, the Cimenterie du Rwanda (CIMERWA) a cement factory in the South West has been using peat-heavy fuel mix (Clinker) as a substitute for heavy fuel in its processing with expectations that its annual expenditure on fuel will be reduced by $30 \%$ (Gahigi 2009).

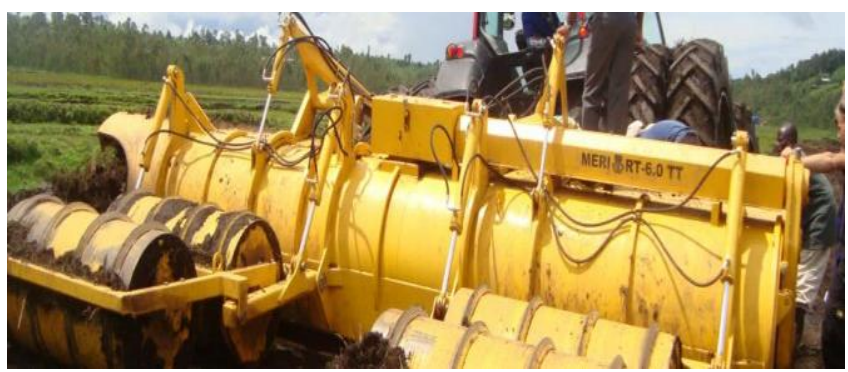

Fig. 7 Tractor preparing the bog (harrowing process) for peat extraction

\subsection{Energy Supply}

The biomass standing stock is estimated at $16,639,795$ tons (ISAR 2007). Hydro power potential is estimated at $300 \mathrm{MW}$, small hydropower sites can provide $30 \mathrm{MW}$. The country could obtain up to 750 MW from methane gas of Lake Kivu and 170-320 MW from geothermal resources. In addition Rwanda has peat reserves estimated at 155 million tons of exploitable dry peat and also daily sunshine is able to provide solar power amounting to $4.5 \mathrm{kWh}$ per square meter.

The conversion loss in 2007 was estimated to $23 \%$ for both commercial and technical losses. Aggregated, $19.34 \%$ represents the loss with charcoal conversion; $1.09 \%$ in electricity transmission (electricity transmission over long distance by old transmission lines and distribution methods, cables that are to a large extent very old) and $2.54 \%$ in electricity production (hydro power and the thermal power generation).

The Economic Development and Poverty Reduction Strategy (EDPRS) projected that a 17.1\% electricity increase per year was necessary to meet the demand $4.9 \%$ per year for the productive sector; $24.5 \%$ per year for urban households and $21.5 \%$ per year for rural households). The road map for the energy sector until 2012 (MINICOFIN 2007) includes:

a. Increased electricity access

b. Reduced cost of service and the introduction of cost reflective electricity tariffs

c. Energy diversification and security

d. Strengthening the governance framework and institutional capacity. 
The Government of Rwanda intended to increase the percentage of the population with access to electricity to $16 \%$ by 2012 through the national Electricity Access Roll out Programme (EARP), which aims to implement the targets formulated in the EDPRS. This translates into at least 350,000 connections to the national grid. Still the target remains difficult to achieve as today only $10 \%$ of households are connected to the electricity grid and consumption is still around $21 \mathrm{kWh}$ per person per year compared to the $60 \mathrm{kWh}$ targeted for 2010. The current electricity grid consists of around $3,300 \mathrm{~km}$ of different voltage levels.

\subsection{Importance of woodfuels}

For sustainable forest management, there are at least four reasons to look beyond woodfuels' contribution to deforestation and to reconsider its socio-economic value.

1. The biomass contribution to the national energy balance remains high. It was supposed to fall from $94 \%$ to $50 \%$ by 2020 , but that target is not realistic given the fact of no change having occurred half-way to the endpoint. Woodfuel remain the main source for household's energy. While energy policy focuses on a rapid transition to modern fuels, access to them remains almost zero.

2. Woodfuel is a useful alternative, in fact. It saves foreign exchange that would otherwise be used to import expensive petroleum products. And electricity generation is low - If all households were to boil water at the same time, the country's generation capacity would need to increase from the current $60 \mathrm{MW}$ to over $600 \mathrm{MW}$.

3. Woodfuels are a renewable resource and, properly managed, the resource can be sustainable at least until economically viable alternatives are available and affordable.

4. Last but not least, woodfuel is an important source of income, and contributes to poverty reduction. In 2007, a survey from MARGE (2008) revealed that the woodfuel sector generated US $\$ 122$ million ( $5 \%$ of GDP), almost twice as much as electricity sales (US\$65 million), three times the value of coffee exports million in the same year (US\$38), and twice that of tea production (US\$48 million). In the same period 300000 rural households drew income from the woodfuel value chain: 8000 charcoalers; 7000 tree fellers; 2000 retailers and 200 to 300 transporters were employed in the sector (MARGE 2008). What is more, some $50 \%$ of this value remains in rural areas, where it is distributed among farmers/wood growers and charcoalers and is, as such, an engine of rural development.
Promoting the woodfuels industry creates more jobs than modern forms of energy. The World Bank/ESMAP estimates of employment per TeraJoule (TJ) of energy consumed in person days indicate that charcoal creates between 200 and 350 jobs per TJ; electricity 80-110 and kerosene only 10 (Mugo 2010). In addition, planting trees for charcoal can be a profitable enterprise, as a survey undertaken in October 2009 shows, where charcoalers make a $58 \%$ profit on each bag produced and the retailer makes 28\% net revenue (Mazimpaka 2010).

The pattern is similar in the other countries in the region. Charcoal production and trade contributes to the economy by providing rural incomes, tax revenue and employment. In the Licuati region of Mozambique $65.4 \%$ of rural incomes are derived from charcoal. In Kenya, ESDA (2005) estimates report a figure of 1.6 million tons worth Ksh 32 billion (US $\$ 1=79.95 \mathrm{Ksh} ; \mathrm{US} \$ 1=2210 \mathrm{Ush}$ ) (ESDA 2005) which, at the $16 \%$ VAT charged by the Kenyan government, should contribute Ksh 5.12 billion in taxes every year. The charcoal industry in Kenya employs about 200000 in production alone. In Uganda, production provides 20 000 jobs and generates more than Ush 36 billion (US\$20 million) a year for rural people (Mugo 2010).

Despite its significant contribution, however, wood fuels have been kept out of the formal economy, mainly because its importance is not well understood and appreciated as:

- First, no comprehensive study has been conducted to prove the specific contribution of woodfuels to deforestation. Given the poor and sometimes inconsistent woodfuels statistics, it is not known exactly how much woodfuels is produced, where and in what form. The same is true for precise quantities of woodfuels consumed by households.

- Second, from 2004 all charcoal and firewood comes from plantations, with a large part from farmers' plantations (NISR 2010), and most of the charcoal is made from Eucalyptus wood on private or communal woodlots.

- Third, charcoal production from natural forest is negligible, as the remnant of rainforest is conserved through the expanded network of federally-protected areas (Miranda 2010).

- Fourth, around $80 \%$ of wood for energy comes from private plantations of less than 0.5 ha (MININFRA 2009) thus falling outside the definition of forest in Rwanda.

Consequently woodfuel in Rwanda can be sustainably produced, or at least most of it can be, and therefore has little impact on deforestation. The 2007 National Forest Mapping (CGIS 2007) reveals that undercover producers invade public forest plantation for timber or poles at $80 \%$; and charcoal making at $4 \%$. Poor forest management and weak regulatory 
enforcement have probably contributed more to deforestation than woodfuels consumption per se.

The regulatory framework needs to properly document the source of woodfuels in order to assess their environmental impact and promote the transparent development of markets. The impact of woodfuel consumption on energy, poverty and environment cannot be addressed in isolation as all of these elements are deeply interlinked.

\subsection{Safeguarding Socio-economic benefits for sustainability}

On the one hand woodfuel consumption contributes to environment degradation because of the toll it can take on forests and woodlands, as well as the air pollution that results from combustion and from wood pyrolysis for charcoal. On the other hand, woodfuel contributes greatly to energy provision and poverty alleviation.

The impact of woodfuel consumption on national forest is not sufficiently understood, at the local and the national levels, for policy makers to address the socioeconomic and environmental conflicts in the woodfuel value chain in an entirely beneficial way.

Socially, woodfuels constitute the country's only affordable source of energy for cooking. Eeconomically, $50 \%$ of the income from all woodfuels trades benefits rural areas and contributes to rural development. Forestry activities generating income vary from timber for construction (35\% of the total income), charcoal (24\%), sawn wood (23\%) and firewood (18\%). Forestry products generate value of about US $\$ 8.5$ million in households with forest plantations (NISR 2010).

Contributing positively as they do, woodfuels issues cannot be addressed only from an environmental perspective. Ignoring their socio-economic benefits takes the regulations in unuseful directions and could even render guidelines fruitless or inoperative, thereby increasing the pressure of woodfuels on forest.

\section{The legal and regulatory framework for woodfuels in Rwanda}

In Rwanda actions to protect and conserve the environment started in the colonial period. Reforestation began in the 1920s and in 1947 tree planting, radical terraces, bench dishes, and anti erosion hedges became colonial policy. After independence in 1962, environmental protection declined for a time; it resumed in 1977, and a national environment strategy was adopted in 1991.

Despite this, and the importance of forest and tree resources, it was only in 1988 that the country endorsed the organic law on forest (Organic law no $47 / 1988$ of $5 / 12 / 1988$ ). The National Decentralisation Policy in 2000; the National Environment Policy in 2003 and the National Land Policy and the National Energy Policy in 2004 were enacted. The National Forest Policy was formulated in 2004 - but only after the country had lost two thirds of its forest in four decades. Through the decentralization policy, districts oversee the management of policies and regulations. At district level there is only one officer in charge of environment and one in charge of forests to assist in integrating environmental and forest issues into the district planning process at the local level. It is obvious that with a constrained budget and given the fact that duties would involve a good deal of field work, this is a particularly difficult responsibility for one official to meet.

The only formally established institution of relevance is the Rwanda Environmental Management Authority, which imposes its vision on forest and biomass energy, and all regulations are seemingly restricted to the aim of preventing environmental abuse explaining why environmental policy overlaps with and directs forest and energy policies in the matter of woodfuels.

The 2004 forest policy targeted the protection of forests and trees in the name of conserving the environment, but to date illicit clearings, poaching and illegal cutting of trees are still common practice.

Since 2003, based on the fact of deforestation and invoking existing forest law (specifically Article 83 as well as Article 49 of the Constitution which addresses environmental protection), the government has raised awareness of the need to control wood product use contribution to deforestation. The most important measures taken included three banning instructions:

1. Instruction No $01 / 2003$ of $14 / 07 / 2003\left(25^{\text {th }}\right.$ Cabinet Resolution referred to forest law) banned tree cutting for scaffoldings; a cutting licence and transport permit were required for all wood products, as well as authorisation from the forest officer for cutting trees within 15 m of roads.

2. Instruction No $0001 / 2004$ of $16 / 07 / 2004$ (09th Cabinet Resolution referred to constitution) banned cutting trees before their maturity, using wood for fires for making bricks and tiles, and all activities in marshlands (this provision referred to Article 49 of the Constitution, not the Forest Law).

3. Instruction No 001/2006 of 03/02/ 2006 required authorisation for cutting, transporting and selling wood, issued by the district for cutting an area of forest of more than 2 ha, and by the sector for an area less than 2 ha. No authorisation is required for cutting for own consumption. The Minister of Forestry must authorise harvesting of GoR forest, the executive secretary of the sector for district forests and trees within 15 metres of roadsides.

The ban policies have not been fully operative, as revealed by a 2008 survey (MARGE 2008) which 
showed that in five of the important charcoal-producing districts $31 \%$ of production was illegal.

The woodfuel management is assumed at the district level. through taxation and permits. One relevant example is the intervention of district officials in terms of regulation of the charcoal sector, each one with its own rules, which vary from outright prohibition on production to a ban during several months of the year. This results in weak law enforcement which leads to poor forest management and, often, to corruption mostly related to speeding up the permit process.

The National Energy Policy and Energy Strategy (EUEI 2009) blames woodfuel for its "potential serious environmental implication" and recognizes that "it can't be sustainable unless managed properly". No transition in household's energy consumption has occurred, the energy consumption is just an enduring biomass mix as it covers around $87 \%$ the net primary energy. Even if the EDPRS national established target access to electricity and modern fuels (35\% of households) or the MDG's target access (50\% of those not connected) were achieved, modern fuels would not be sufficiently competitive to reduce the dependence on biomass to the $50 \%$ target in 2020 . Petroleum fuels and electricity remain unaffordable for households, who will continue to depend on lower-cost biomass fuels at least for cooking (see Table 1). This makes it relevant to revalue the importance of biomass energy, to make its supply sustainable and to avoid encouraging the use of petroleum products except where biomass energy is not competitive, as in industry and transport.

The energy policy and energy strategy under revision proposes the removal of regulatory restrictions such as bans. These would be efficient if they could be only applied to natural woodland. Removal of bans and the very bureaucratic wood harvesting permit issuance would improve management and support the woodfuels value chain.

Table 1 Cooking cost with different fuels (MININFRA, 2008)

\begin{tabular}{llc}
\hline \multicolumn{1}{c}{ Fuel } & \multicolumn{1}{c}{ Stove } & $\begin{array}{c}\text { Cost } \\
\text { (\% of charcoal } \\
\text { cost) }\end{array}$ \\
\hline Charcoal & Traditional & 100 \\
& Improved & 77 \\
Fuelwood & Traditional & 57 \\
& Improved & 44 \\
Briquettes & Solid wastes & 68 \\
& Papyrus charcoaled & $89-103$ \\
& Charcoal dust & $80-90$ \\
Kerosene & & 110 \\
Electricity & & 155 \\
LPG & & 318 \\
\hline
\end{tabular}

\subsection{Provisions vs practices in policy instruments}

Section 1 of the forest law (Art 64-73) clarifies procedures for cutting and replenishment. In the case of sustainable cutting, mature trees are marked by the forest officer and only these may be cut. The permit is valid for 3 months, with a 3 months extension period, and, once applied for, the permit is issued in less than 30 days. The only tax mentioned in the law is the one percent of the sale from any type of forest to be paid to the National Forest Fund (Revenues are supposed to be channeled into the support of more sustainable forestry practices including reafforestation in the degraded wood woodlands, seedlings nursery improvements, grants or subsidies to support private and community woodlots, and popularization of forestry techniques). No permit is required for wood for own consumption. The cut woodlot stand must be sustainably managed by the owner and the in charge of forest at local level bears the responsibility of monitoring the replenishment and evaluating the post harvest replenishment process.

Once the forest officer has visited the stand to be harvested and measured the area to be cut, the trees are not marked - as confirmed by charcoal makers, which means that even not mature trees are cut, leading to clear felling which is against the instruction No $01 / 2003$ establishing a ban of cutting trees before maturity.

In addition, before the permit is issued, extra taxes to $1 \%$ tax for the NFF are paid for the issuance (transport for the forest officer to and from the area of harvest (As the forest officer has no means of transport, the charcoal maker must pay for his transport to assess if the stand is mature), fees for the Education Fund and for any other ongoing district activity). The $1 \%$ tax for NFF is paid at the bank. The extra taxes constitute the district's income and are paid to the district cashier.

The cutting permit is legally supposed to last 3 months, but is often limited to one week, depending on the area to be cut. Practically it is only valid for one month with 15 days extension as its extension is left to the issuing authority's discretion. That short period of time (as the charcoal maker will be fined if the carbonization in not completed after one month) reduces the possibility of wood drying and therefore the carbonization efficiency. The forest officer, due to financial or time limitations, does not come back to check for post harvest management, and the cut stand can be easily converted to agricultural land. When not available, the forest officer sends an untrained delegate (local defense - proximity police at sector level) for estimates of maturity.

The collection of statistics on forest and forests products are required by all wood products exploitation permits but it is not done. The only reliable consumption figures come from industry (tea factories) and institution like prisons and schools, as they have to report their wood consumption with their monthly expenditure. Household consumption statistics are nonexistent. This poor data collection makes it impossible to get a real picture of the national woodfuel consumption to determine its impact on deforestation. The inventory and statistics keeping, the responsibility of the National Land and Forest Research Centre (LFRC) (The centre was supposed to be responsible for 
inventories and statistics, research on wood technology and utilization, forest economics and forest products marketing) at district level, is not done as the LFRC is not yet operational. Obviously, if woodfuel statistics are not kept at district level, they will not be available on a national basis, and all planning in the woodfuel sector is based on estimates.

Section 2 of the law (Art 74-79) clarifies procedures for clear felling (excision) and replenishment procedures. Permit for such cut are requested and issued only on the understanding that whatever area is cut is replaced by new planting. Before the forest excision an equal area of forest in another place must be afforested. Due to the smallness of land holding forest excision should be prohibited. Once it is allowed, the forest owner will not have another free piece of land for new afforestation and excised land can be converted to agriculture land. Here again, due to financial constraints, the forest officer will not be able to monitor the survival rate of any tree planted.

Section 3 (Art 80-82) concerns the selling and transport permits, which are supposed to be given free and issued for one round trip only. In practice, validity time is left to the discretion of the authorizing authority, which can easily lead to corruption.

Agroforestry is highly recommended by the law but is not practiced. The reasons for this are: trees may lower crop yields; the yield of crops per unit area may be lower than for the monocultures; the time-lag from planting to getting the economic benefits of trees may be longer than people can afford in comparison with other cash crops, as it takes longer for trees to acquire economic value.

The Forest Protection Service to monitor policy instruments only operates in national parks and reserves. Even the checking points at the productions site exits and at the city entrances were removed in April 2004, making illegal trading a common practice. These checking points were local sources of bribery and corruption, as they were locally established by sectors or even cells without legal status.

As most of the required management measures fall on the forest officer, weaknesses can be partially attributed to weak institutional capacities. The requirements are beyond the existing staff capabilities (numerically and financially).

Hence forests have been degraded, not exclusively by need for fuels, but mainly as a result of deliberate clear felling, conversion for agriculture and housing, due to lack of monitoring and evaluation of post-harvest management. The increasing distances for charcoal provision (on average $80 \mathrm{~km}$ to $180 \mathrm{~km}$; the widening circles of deforestation around expanding cities; the landscape changes and the reduction in area of natural forests and parks are evidence of the process.

\subsection{Weaknesses of energy and forest policies}

The national forest policy was prepared in the period where the country was facing heavier priorities and problems. It is presented under a scope of problems and constraints, little in the way of solutions and opportunities. The policy recognizes the lack of national institutional capacity, the weakness of forest regulation implementation, and the lack of data on consumption of wood and by-products which would enable appropriate economic studies. The policy does not recognize the need to meet, on a sustainable basis, people's need for wood and other forest products and services. Rather, it calls for a reduction in "dependence on woodfuel as a source of energy" through switching to unavailable and unaffordable modern fuels.

These weaknesses in providing solutions and opportunities may be the cause of a low level of interest in tree planting and monitoring. The 2008 National Agriculture Survey revealed that $28 \%$ of surveyed households reported having not a single tree on their land, and only $15 \%$ had planted new trees on their land in 2008. In some areas there is an understood high percentage loss of trees planted as on overall losses amounted to close to $30 \%$ of the trees planted in 2008 (MINICOFIN 2009).

In summary, the Energy and Forest Policies clearly are weak. As they are under revision, they must be less sectoral but more integrated into national sustainable development if forests are to be both protected and still contribute to economic development. As long as the two policies neglect to recognize the socio-economic value and importance of woodfuels, especially for the rural areas, sustainable woodfuel production will not be achieved and the pressure on forests will increase.

\subsection{Weaknesses of bans as a regulated production measure}

In an effort to halt the damage caused by wood products trade, the GoR imposed restrictions on production and transportation of wood products mainly charcoal. The most controversial are the ban on use of woodfuels in bricks and tiles burning and charcoal production. Having no alternative producers work clandestinely. Once bricks or charcoal have entered the urban areas - even fraudulently - their trade becomes legal.

Bans, permits and all related authorizations were put in place as a measure to regulate production and protect forests. Ban periods; permit delivery and taxation were left to the discretion of the district. In terms of regulation the decentralized tax and delivery system without general national guidelines is a source of undercover production by opportunists and corruption; too bureaucratic for producers, while - 
-decentralised units make policy implementation difficult and illegal products evade taxes.

Everywhere where bans have been imposed, they have proven to be unhelpful in protecting forests, but have increased illegality in production. In Chad and Tanzania bans on charcoal were removed after causing social unhappiness as they were associated with bribes; in Uganda after a ban on charcoal production lasting twenty years charcoal is still the main urban fuel (ZULU 2010).

The outcome of the 1930 decree requiring prior authorisation to any tree cutting or sale of wood is uncertain, but its successor of 1993 certainly failed. The 2003, 2004 and 2006 instructions with the same injunctions also failed, with $50 \%$ of woodfuels reported to evade taxes (MININFRA 2007); 31\% of surveyed char coalers engage in illegal charcoaling (MARGE 2008); illegal charcoal production constitutes a loss of 441964 $\mathrm{t} / \mathrm{yr}$ of wood that would not be cut if charcoal was fully legal (wood is not dried which reduces the carbonization efficiency. When wood is well dried the efficiency is assumed to be $14 \%$, while when not dried it drops to $12 \%$ ), representing $29 \%$ of the total volume of wood needed to meet the national annual consumption of 150000 tons (MININFRA 2009); wood is used for scaffolding, bricks and tiles are baked with woodfuel, charcoal is made and transported by night. If, as is clearly the case, the bans do not work why continue with them?

\subsection{Financial instruments}

For petroleum products taxation is clear: value added tax; import duties; consumer tax and a contribution to the national road fund. On average, retail prices of petroleum products are about $100 \%$ higher than acquisition costs. In the traditional energy sector, a lack of coordination, transparency and a unified taxation approach leads speculation pushing prices upwards. Currently, taxes on traditional fuels are set by the districts that choose their own levels; some are levied in the form of a permit rather than a tax per se. For example, a wood exploitation permit in former Butare and Cyangugu provinces is taxed at $2000 \mathrm{RWF}$ monthly, in Kibungo the tax is set at 4300 RWF per hectare per month; in Ruhengeri and Gisenyi Provinces, except permit charges, no tax is paid (Butare 2004). The only official tax is $1 \%$ for the NFF, but its total value, including additional costs for obtaining the permits (travel time to the District office to register the application; sometimes contribution to travel cost of the District official so that he can visit the plantation; additional travel to verify that the permit is issued; sometimes one need to pay local official a small fee for expediting the process, etc.) was calculated to be about $9 \%$ of the production cost, based on a survey conducted with wood owners, charcoal makers and transporters in October 2009 (Mazimpaka 2010).

\subsection{Institutional coordination}

The Ministries of Infrastructure, Natural Resources, Agriculture, Local Governance, Finance and Planning, and Commerce all play a role in woodfuel commoditisation. The Ministry of infrastructure deals with user aspects of biomass such us rational use, efficiency of consumption and search of alternative fuels to biomass. The supply side is covered under the Ministry of Natural Resources within the forest and environment departments; it deals also with land ownership. This may seem logical as one has forests under his responsibility and the other has energy, but there is no coordination on the supply and demand between the ministries. At district level, authorities are not aware of the markets for woodfuels for local development but look only to how these can contribute to their own budget.

This plethora of institutions leads to a very small output in terms of planning, monitoring and evaluation. No institution is directly and fully accountable for the woodfuel value chain; there is rather a set of institutions, each with different interests and responsibilities in the sector leading to the excuse that "It is Somebody Else's Problem" (Diamond, 2005). The consumption of biomass energy, its sourcing, production, transport and trade, all fall under separate regulatory environments, so that coordination is severely affected. Institutional coordination is lacking as there is no inter-ministerial task team to manage the sector or formulate strategies. Even with good policies and regulations, best practice in policy implementations and law enforcement are of prime importance to reduce the pressure of woodfuels on the already-strained forest resources.

\section{The road ahead}

Given that no proper forest management plans and consistent statistics are available to itemize the individual contribution of woodfuels to deforestation, woodfuels are subject to speculation which results in limiting their value chain. Restrictive policies, underfunding, understaffing, and inertia on the part of the bureaucracy, all hinder the policy instruments. As some of the regulations (bans and over-bureaucratic licensing processes) were limiting the socio-economic benefits traditionally gained from the woodfuels trade, they missed the objective of alleviating their pressure on wood resources.

National established targets to substitute or reduce woodfuel consumption are not achieved and policies have not reduced deforestation. This could be done by shifting the present forest management at district level to a Community Based Forest Management (CBFM) through Community Based Woodfuel Production (CBWP). The concept of community-based woodfuel production transfers the management 
responsibilities formerly administered by a country's national or state-level forest service to local authorities. This can be a community comprising several villages (as in Senegal) or a single village (as in Niger, Chad) located in proximity to productive forests. They must organize a management committee as their representative body, and must apply sustainable management techniques to forest resources. In return, interested villagers create user groups and are entitled to harvest and sell the forest products for their own benefit. A service contract between the user groups and the village management committee specifies harvesting areas, standards and quotas.

The socio-economic benefits will catalyze best management practices, while at the same time the impact of woodfuel consumption on energy, poverty and environment will be addressed.

The CBWP is an approach for sustainable production of woodfuels with a commercial focus. They have been in operation for 20 years in SSA and have proven to have more successes than failures in forest management where properly addressed (Miranda, 2010). CBWP must be regarded as part of an overall rural development strategy, replacing the quasimonopolies enjoyed by urban-based charcoal traders. The approach aims to improve rural livelihoods and thereby helps to reduce poverty while at the same time protecting the environment and promoting democratic practices.

One of the criteria for both strategies' adoption is that commercial woodfuel is traded and has economic value, with a clear commercial interest for all those involved: farmers and rural villagers, traders and consumers (Miranda 2010).

The strategy is based on the fact that "Sustainable forest management depends on a balanced combination of effective forest governance/law enforcement, and particular incentives for local stakeholders (such as technical assistance and promotion of transparent and equitable market frameworks) who together should facilitate the emergence of true market prices" (Miranda 2010).

Once legal and regulatory frameworks are scrupulously enforced through CBWP, woodfuels get their true value: taxes revenues are paid to the treasury; producers are paid according to true cost, and traders' profit increases. One risk is the slight price increase for woodfuels, which is profitable for producers, but affects consumers negatively. Through the CBWP, the socioeconomic benefits work as incentive to farmers to plant more trees and sustainably manage them. The charcoal producers adopt more efficient production to maximize their incomes. The slight prices shift upwards catalyses the consumers' saving and/or the substitution culture to curb the energy expenditure. Therefore producers and consumers contribute to the reduction of woodfuel pressure on forest resources. Biomass energy is safeguarded by planting more, saving more and substituting more: this is the cornerstone to alleviate the pressure on woodfuels resources.

Where consumers adopt the energy saving culture, the improved stoves and increased charcoal efficiency have a tremendous potential for saving wood. With the CBWP approach people could be taught and trained on energy saving, improved cook stoves promotion and dissemination. Improved wood and charcoal stoves are more cost effective way to save wood as opposed to producing more wood to meet population driven increase in demand over time. The improved stoves dissemination in Rwanda, for example, is known to save between 25 and $40 \%$ of the wood vis-a vis the 3 stone because of higher thermal efficiency (MINITRAPE 1993). Planting and saving well combined with growing of high calorific value species contribute a lot to forest protection. For example, if an equal volume of wood saved were to be produced saving more is far most cost effective than planting more.

Will CBWP succeed in Rwanda? Rwandans have proven positive feedback to the "forest scarcity hypothesis mechanism": meaning that deforestation makes forest products scarcer and increases the economic value of remaining forests. This increased value in turn directly translates into better forest management and the establishment of woodlots and tree plantations. With growing scarcity of woodfuel, agricultural production gradually loses its relative advantage, and woodfuel production becomes a viable option for local landholders. As a consequence, forest cover rise (Miranda 2010).

While the woodfuels trade is at present profitable to districts and to urban charcoal masters, it leaves local people with very little to show for their labor in tree growing and woodfuel production, including charcoal making. The CBWP approach can support rural economic development and improve sustainability of woodfuel resources, as the rural people producing the fuel feel themselves as stakeholders sharing benefits, and not as intruders or forest invaders - as is the case today with the district forest management-. CBWP will ensure a fairer sustainable and equitable distribution of the woodfuel value chain income. When local people share benefits they are more stimulated to improve production processes and de facto become forest caretakers in plantation and management strategies.

\section{Conclusion}

The heavy reliance on woodfuels in primary energy and energy consumption in Rwanda is often seen as intrinsically damaging to the environment in general and forests in particular; despite its importance, woodfuel is not given the policy attention deserved and is not properly regulated. 
Factors such as uncontrolled population growth, land tenure, poverty, environment and political power/rule and poor governance have had more impact on forests than woodfuel consumption per se. The impacts of woodfuel use are not necessarily negative for all groups of actors or under all circumstances. Nor do they necessarily lead to permanent environmental change, as in Rwanda where woodfuels are not sourced from (natural) forests or areas defined as such. Misunderstandings of this situation, coupled with topdown forest management at district level, have led to restrictive guidelines ignoring the socio-economic benefits which flow from the woodfuels value chain. Over-bureaucratic processes in an understaffed and underfunded sector have proven to be ineffective.

Environmental policies overlap the biomass energy sector, with the ministry of natural resources handling the supply side and the ministry of infrastructure dealing with the demand side. This duplication, not relevant to the modern energy sector (Petroleum products importation, storage and distribution fall under the Ministry of Commerce and Electricity under the Ministry of Infrastructure through the national utility EWSA), has shown itself to be ineffective. Energy policy recommends a move away from traditional biomass energy in favor of unavailable and unaffordable modern fuels. The environmental policy imposes very restrictive harvesting regulations which prompt the woodfuels industry to operate illegally, leading to production which is not sustainable. Forest protection is not achieved, nor is energy sustainably provided or poverty alleviated.

Given that in the foreseeable future biomass will remain the primary source of energy, it is imperative to develop the biomass energy sector in a way that is more oriented to energy for poverty alleviation and more environmentally sound, before the transition from traditional to modern energy sources can be achieved. A participatory approach where the local populations have their contribution in production and management could be more successful as the targeted integrated development must be achieved with the people and not for the people.

In order to reinforce policy instruments, the community forest management through the CBWP can be seen as viable strategic approaches to alleviate the pressure of fuel demand on forest resources while increasing the socio-economic benefits flowing from the woodfuel industry. The CBWP devolve responsibilities to local communities for sustainable, environmentally sound forest management and poverty alleviation. In that way the woodfuel production and consumption impacts on energy, poverty and environment are addressed not in isolation but simultaneously. They have proven to be successful in some sub-Saharan Africa countries (Senegal, Niger, and Madagascar) and should be successful in Rwanda too.

\section{References}

Butare, A. \& Hughes, M. (2004) Energy biomass supply survey. Ministry of Finance and Economic Planning, Kigali, Rwanda.

CGISR-NUR (2007) National Forest Mapping. Butare, National University of Rwanda, Rwanda

Diamond, J. (2005) Collapse. Penguin, London, UK.

Gahigi, M. (2009) Peat mining saves CIMERWA. The Newtimes. Retrieved June 12, 2009, http:// www.newtimes.co.rw

GTZ (2008) Rwanda biomass energy strategy: Executive summary. Gesellschaft fur Technische Zusammenarbeit, Kigali, Rwanda.

IEA (2010) Energy poverty: How to make modern energy access universal. International Energy Agency, Paris, France.

ISAR (2007) Inventaire des ressources ligneuses au Rwanda. Kigali, Rwanda: Institut des Sciences Agronomiques du Rwanda.

Kamweti, D. (1984) Fuelwood in Eastern Africa: Present Situation and Prospects. FAO W/R 0064, Rome.

Kebede, E., Kagochi, J. \& Jolly, C.M. (2010) Energy consumption and economic development in sub-Sahara Africa. Energy Economics, 32(3), 532-537.

Leach, G. M. (2009) Beyond the woodfuel Crisis people, land and trees in Africa. Earthscan, London.

Marcoux, A. (2000) Population and deforestation. Rome, Italy: Population and the environment. FAO.

Mazimpaka, E. (2010) Rwanda Facing a Woodfuel Crisis. International Conference on Domestic Usage of Energy (pp. 33-40). Cape Peninsula University of Technology, Cape Town.

MINICOFIN (2007) Economic Development and Poverty Reduction Strategy. Ministry of Finance and Economic Planning, Kigali, Rwanda.

MINICOFIN (2009) Economic Development and Poverty Reduction Strategy (EDPRS) Implementation Report. Ministry of Finance and Economic Planning, Kigali, Rwanda.

MINITRAPE (1993) Bulletin des Statistiques Energétiques du Rwanda, Edition 1992. Ministère des Traveaux Publics et de l'Energie, Kigali, Rwanda.

MININFRA (2007) Rwanda Biomass Energy Strategy, Volume 2Analysis. Ministry of Infrastructure, Kigali, Rwanda.

MININFRA (2009) Biomass Energy Strategy, Volume 3: Rural Supply and Demand. Ministry of Infrastructure, Kigali, Rwanda.

Miranda, R., Sepp, S., Ceccon, E., Mann, S. \& Singh, B. (2010) Sustainable production of commercial woodfuel: Lessons and guidance from two strategies. Energy Sector Management Assistance Program, Washington, DC

Mugo, F., \& Ong, C. (2006). Lessons of eastern Africa's unsustainable charcoal trade.ICRAF working paper no. 20. World Agroforestry Centre, Nairobi, Kenya.

Mwampamba, T.H. (2007) Has the woodfuel crisis returned? Urban charcoal consumption in Tanzania and its implications to present and future forest availability. Energy Policy, 19(2007) 4221-4234, doi:10.106/j.enpol.2007.02.10.

NISR (2008a) Demographic statistics. National Institute of Statistics of Rwanda, Kigali, Rwanda.

NISR (2008b) Rwanda in statistics and figures. National Institute of Statistics of Rwanda, Kigali, Rwanda.

NISR (2010) Rwanda Development Indicator 2009. National Institute of Statistics of Rwanda, Kigali, Rwanda.

ProBEC (2008) A synthesis report on biomass energy consumption and avalability in South Africa. Pretoria, Programme for Basic Energy and Conservation in Southern Africa.

REMA (2009) Rwanda state of environment and outlook. Rwanda Environment Management Authority, Kigali, Rwanda.

Statistics South Africa. (2007) Community survey 2007. Statistics South Africa, Pretoria, South Africa 
Citation: Mazimpaka, E (2014) Woodfuel in Rwanda: Impact on Energy, Poverty, Environment and Policy Instruments Analysis. Int. Journal of Renewable Energy Development, 3(1), 21-32 doi: $\underline{10.14710 / i j e d .3 .1 .21-32}$

$\mathrm{P}$ a g e $\mathbf{3 2}$

UNDP (2009b) The energy access situation in developing countries: review focusing on the least developped countries and sub-Sahara Africa. United Nations Development Programme, New York.

UPEGAZ (2004) Physico-chemical study of Lake Kivu. Unit for the Production and Exploitation of Lake Kivu Gaz., Kigali, Rwanda.
WB (2008) Building sciences, technology and innovation in Rwanda: Developing pratical solutions to pratical problems. World Bank Author, Kigali, Rwanda.

Zulu, L. (2010) The forbidden fuel: Charcoal, urban woodfuel demand and supply dynamics, community forest management and woodfuel policy in Malawi. Energy Policy, 38(2), 3717-3730. doi: 10.1016/j.enpol.2010.02.05. 